\title{
Evans Stage IV
}

National Cancer Institute

\section{Source}

National Cancer Institute. Evans Stage IV. NCI Thesaurus. Code C85411.

Tumor spread to distant anatomic sites. 